\title{
Perceptions of Coach Social Identity and Team Confidence, Motivation and Self-Esteem
}

\author{
Tony Cassidy, Paul Cummins, Gavin Breslin, Maurice Stringer \\ University of Ulster, Coleraine, UK \\ Email: t.cassidy@ulster.ac.uk, Cummins-P1@email.ulster.ac.uk, g.breslin@ulster.ac.uk, \\ m.stringer@ulster.ac.uk
}

Received 16 June 2014; revised 13 July 2014; accepted 7 August 2014

Copyright @ 2014 by authors and Scientific Research Publishing Inc.

This work is licensed under the Creative Commons Attribution International License (CC BY). http://creativecommons.org/licenses/by/4.0/

(c) (i) Open Access

\section{Abstract}

The social identity theory of leadership has potential application to sport coaching research but lacks a usable measure. We administered a pool of 51 items to 271 sport science students aiming to produce measures of coach prototypicality and team identity. Principal component analysis (PCA) produced a 10-item Coach Social Identity Scale (CSIS), and a 15-item Team Social Identity Scale (TSIS). The study produced initial evidence of reliability and validity for both the CSIS and the TSIS, providing a potentially useful set of measures with which to explore the role of social identity in coaching.

\section{Keywords}

Social Identity, Sport Coaching, Sport Confidence, Sport Motivation

\section{Introduction}

Chelladurai and Saleh (1980) were among the first to argue the utility of applying Leadership Theory in sport and since then a number of studies have explored this relationship (e.g. Callow, Smith, Hardy, Arthur, \& Hardy, 2009; Charbonneau, Barling, \& Kelloway, 2001; Miller \& Carpenter, 2009; Rieke, Hammermeister, \& Chase, 2008; Smoll \& Smith, 1989). Though these studies demonstrate to some degree the effectiveness of leadership models in explaining coaching behavior and performance, definitions of coach leadership fail to reflect a true understanding of either the coaching process or leadership (Vella, Oades, \& Crowe, 2010). The limitations in terms of definition are further linked to both the measurement and application of coach leadership theory. Studies cited above have looked at cognitive-mediational models (Smoll \& Smith, 1989), transformational leadership 
models (Callow et al., 2009; Charbonneau et al., 2001) and more recently servant leadership (Rieke et al., 2008), altruistic models (Miller \& Carpenter, 2009), and authentic leadership (Luthans \& Avolio, 2003). One promising perspective that seems to have been missed or ignored is the social identity theory of leadership (El- lemers, De Gilder, \& Haslam, 2004; Haslam \& Platow, 2001; Hogg, 2001, 2006, 2007; Hogg, Fielding, Johnson, Masser, Russell, \& Svensson, 2006).

Current definitions of leadership as a relational, strategic, and complex social process have exposed the limitations of traditional models (Avolio, Walumbwa, \& Weber, 2009; Haslam, Reicher, \& Platow, 2011; Vroom \& Yago, 2007), and provided a suitable breeding ground for a Social identity perspective. Social identity theory refers to, "the individual's knowledge that he belongs to certain social groups together with some emotional and value significance to him of this group membership" (Tajfel, 1982: p. 292). Sharing this sense of identity creates cohesion within a group and essentially motivates individuals to go the extra mile to defend and enhance a positive identity for the group; the individual's self-esteem depends on a strong, positive identity for salient groups, e.g. their football team (see Hogg, 2001; Hogg \& Abrams, 1990). An effective leader will need to be seen to share the group identity, i.e. to espouse the shared values, attitudes, beliefs and desires; in other words to be seen as a group member (Hogg, 2001). Group members will hold a prototype of a typical group member and the closer any individual matches the prototype the more they will be liked and respected, i.e. they become socially attractive. This combination of social attraction and prototypicality enables individuals to emerge or operate as leaders, exerting social influence on the group (Hogg, 2001). This model of leadership has been tested in numerous studies (Ellemers et al., 2004; Haslam et al., 2011; Haslam \& Platow, 2001) and shown to impact on motivation, performance, and team cohesion. In addition to leadership currently being defined as a complex social process, so too is coaching. Vella, Oades and Crowe (2010) define coaching as, “complex social process that is constituted and maintained by a set of reciprocal, interpersonal relationships and permeated by contextual constraints" (p. 425). It seems to follow that a social process model of leadership is more likely to be useful as a model in coaching.

In order to explore a social identity theory of leadership in coaching there is the issue of measuring social identity. Most of the studies that have tested the theory in work settings have been experimental studies which are not easily undertaken in real world settings. Hence a questionnaire measure is desirable. A literature search identified 13 possible scales (see Table 1) and these were reduced to 6 which were finally used in developing items for the current study. These were, 1) the Collective Self-Esteem Scale (CSES) (Luhtanem \& Crocker, 1992), 2) the 3-component Social Identification Measure (Ellemers, Korkenaas, \& Ouwerkerk, 1999), 3) Karasawa’s (1991) 2-component measure of social identity, 4) Mael and Asforth’s (1992) 6-item measure of global organizational identification, 5) Doosje, Ellemers, and Spears' (1995) 4-item global identification measure, and 6) Hinkle, Taylor, Fox-Cardamone, and Crook’s (1989) 3-component SI measure.

Evidence suggests that the social identity approach to leadership provides a useful model for understanding and developing effective coaching, yet it has not been applied to the area. In order to apply it there is a need to develop a measure. Drawing on existing measures of social identity developed for use in work settings the current study aimed to devise a pool of items from which to develop measures that can be used to assess a social identity model of leadership in coaching settings. The aim is to devise measures that can be applied to both coaches and team members, and test the utility of that measure.

\section{Method}

\subsection{Design and Sample}

A survey using questionnaire data collection was administered to 271 sport science students (229 males and 42 females) ranging in age from $18-38\left(M_{\text {age }}=21.5, S D_{\text {age }}=4.5\right)$.

\subsection{Measures}

A pool of 51 items was derived from the 6 measures described in Table 2, after duplicate items were removed. The items were revised so as to be applicable to a sport setting, and could be used to reflect team members' perceptions of their coach. For example "It would be accurate to describe our coach as a typical member of our team" or "I identify with my team coach". The items were presented with a 5-point Likert scale from 1 (strongly agree) to 5 (strongly disagree). 
Table 1. Scales accessed in constructing an item pool for the current study.

\begin{tabular}{lll}
\hline Name of scale $\quad$ Authors & $\begin{array}{l}\mathrm{N} \text { of } \mathrm{N} \text { of } \\
\text { items factors }\end{array}$
\end{tabular}

Identification with a psychological group (IDPG)

Mael \& Tetrick (1992) 10

\section{Share} Shared characteristics

Multidimensional Organisational

Allen \&

Commitment Scale Meyer (1990)
Affective commitment 24 3 Continuance commitment Normative commitment
Measure of identification with a psychological group or organization, defined as the perception of sharing experiences of a focal group and sharing characteristics of the group's members

Cognitive

Organisational

Identification

Bergami \&

(Self-Categorisation) Bagozzi (2000)

Scale

$\begin{array}{ll}{ }^{*} \text { Collective Self } & \text { Luhtanen \& } \\ \text { Esteem Scale } & \text { Crocker (1992) } \\ \text { (CSES) } & \end{array}$

Crocker (1992)

Measures positive feelings of identification with and attachment to the organization, the extent of commitment by virtue of the costs of leaving the organization, and the feelings of obligation to remain with the organisation

Scale consists of a largely visual item and a verbal item. The former asks respondents to directly express their felt degree of overlap between their own identity and the organisation's identity

Public collective self-esteem Evaluation of one's social identity: scale was Private collective self-esteem constructed to assess individual differences Importance to identity in collective, rather than personal, self-esteem

Organisational

Identification

Questionnaire (OIQ)

Cheney (1982)

Organisational

Commitment

Porter, Mowday,

Questionnaire (OCQ)

\& Steers (1974)

*The 2-component

"Group

Identification”

Karasawa (1991)

measure

*The 3-component

Ellemers,

SI measure

Kortekaas, \&

Ouwerkerk (1999)

10

Group self-esteem

Loyalty

Similarity

Membership

1 Organisational commitment

Identification

2 with group

Identification with group members

*The 6-item measure of organizational Mael \& identification Ashforth (1992)

6

1 Organizational identification
*The 4-item global identification measure

Doosje et al. (1995)

Hinkle, Taylor,

${ }^{*}$ The 3-component SI measure
Emotional identification Individual/group

3 opposition

Cognitive aspects of identification
This measure is used to gauge the degree to which someone identifies with their organisation along three factors (loyalty, similarity, membership)

Global measure used to gauge the degree to which someone is committed to their organization

Initially used originally to examine Japanese school students' identification with their school. Karasawa's measure differentiates between identification with the organisation, and identification with the organisation members

Self-categorisation, commitment to the group and group self-esteem as related but distinct aspects of social identity

Popular organisational identification scale based on high inter-item reliability and ease of administration. Scale has been criticized for focusing on the affective aspects of identification at the expense of the cognitive

A basic scale measuring identification with certain categories. Originally used for Dutch students and their identification as "psychology students" but like other social ID measures, it can easily be adapted for other organisational settings by substituting the name of the relevant organisation. As this measure is short and global, it is suitable as a measure of both social ID and social ID salience

This scale was devised as an adaptation from Brown Condor, Mathews, Wade, and Williams (1986) group ID measure. The authors identified subscales which were differentially associated with specific forms of intergroup behavior 


\section{Continued}

\begin{tabular}{|c|c|c|c|c|c|}
\hline $\begin{array}{l}\text { A single-item } \\
\text { measure }\end{array}$ & $\begin{array}{l}\text { Haslam, Oakes } \\
\text { et al. (1999) }\end{array}$ & 1 & 1 & $\begin{array}{l}\text { Social ID } \\
\text { Salience }\end{array}$ & $\begin{array}{l}\text { This single item global measure of identification is } \\
\text { highly correlated with other global measures of } \\
\text { social and organisational identification }\end{array}$ \\
\hline $\begin{array}{l}\text { The } 10 \text {-item } \\
\text { measure of social } \\
\text { identification }\end{array}$ & $\begin{array}{l}\text { Brown et al. } \\
\text { (1986) }\end{array}$ & 10 & 1 & Social identification & $\begin{array}{l}\text { This measure was the first social ID measure ever } \\
\text { developed, and was modeled on a previous } \\
\text { measure of ethnic identification }\end{array}$ \\
\hline
\end{tabular}

Note: ${ }^{*}$ is used to identify scales used in the construction of the item pool.

Table 2. Factor loadings and psychometric properties of the Coach Social Identity Scale (CSIS).

\begin{tabular}{|c|c|c|}
\hline $\begin{array}{l}\text { Factor 1: Coach Social Identity: Eigenvalue = 4.4; } \\
\text { Variance }=43.8 \% ; \text { Cronbach Alpha }=.88\end{array}$ & Item-Total correlation & Factor loading \\
\hline 1) Our coach is just like one of us & .591 & .624 \\
\hline 2) It would be accurate to describe our coach as a typical member of our team & .635 & .635 \\
\hline 3) I see our coach as a member of the team & .652 & .667 \\
\hline 4) Our coach would feel good to be described as a typical member of the team & .604 & .578 \\
\hline 5) I don't feel our coach is one of us & .701 & .701 \\
\hline 6) I am proud to acknowledge that our coach is a member of the team & .494 & .528 \\
\hline 7) I feel strong ties with my team coach & .719 & .840 \\
\hline 8) We often socialise with our team coach & .488 & .499 \\
\hline 9) I'm glad to have a coach who is a member of the team & .597 & .585 \\
\hline 10) I identify with my team coach & 675 & .860 \\
\hline
\end{tabular}

In order to measure team member's sense of identification with the team the same pool of 51 items was also reworded to be applicable to team members' ratings of their own relationship with their team. For example "It would be accurate to describe me as a typical member of our team" or "I identify with my team". The items were presented with a 5-point Likert scale from 1 (strongly agree) to 5 (strongly disagree).

In addition 2 standardised measures, as described below, were used.

The Sport Motivation Scale (Pelletier, Fortier, Vallerand, Briere, Tuson, \& Blais, 1995). The Sport Motivation Scale (SMS) is a measure of contextual motivation which is intended to identify the perceived reasons for participating in sport. It measures the three forms of motivation, intrinsic motivation $(\alpha=.82)$, extrinsic motivation $(\alpha=.85)$, and amotivation $(\alpha=.71)$, reflecting varying degrees of self-determination along a motivation continuum (Deci \& Ryan, 1985). Participants are asked to respond to the question, "Why do you practice your sport?" with such items as, "for the pleasure I feel in living exciting experiences". Participants respond using a sevenpoint Likert-type scale ranging from 1 (does not correspond at all) to 7 (corresponds exactly).

The Carolina Sport Confidence Inventory (CSCI) (Manzo, Silva, \& Mink, 2001) is a 13-item scale based on a two-factor model incorporating sport optimism $(\alpha=.79)$, and sport confidence $(\alpha=.87)$ as a composite of perceived competence and perceived control. Participants are presented with 13 pairs of opposing statements to choose between and then indicate whether it is somewhat or very true for them. See example of item 1 below.

\begin{tabular}{|c|c|c|c|c|c|c|}
\hline $\begin{array}{l}\text { Very } \\
\text { True } \\
\text { For } \\
\text { Me }\end{array}$ & $\begin{array}{c}\text { Somewhat } \\
\text { True } \\
\text { For } \\
\text { Me }\end{array}$ & $\begin{array}{l}\text { I feel I am not very } \\
\text { good when it comes } \\
\text { to playing sports }\end{array}$ & OR & $\begin{array}{l}\text { I feel I am really } \\
\text { good at many } \\
\text { sports }\end{array}$ & $\begin{array}{c}\text { Somewhat } \\
\text { True } \\
\text { For } \\
\text { Me }\end{array}$ & $\begin{array}{l}\text { Very } \\
\text { True } \\
\text { For } \\
\text { Me }\end{array}$ \\
\hline
\end{tabular}




\subsection{Procedure}

Convenience sampling was used to distribute questionnaires to 450 sport science students, from whom 271 completed measures were received, approximately 60\% response. Data was entered into SPSS for analysis.

\section{Results}

A principal component analysis (PCA) with orthogonal rotation (varimax) into simple structure was conducted on the 51 items devised to reflect team members' perceptions of their coach. The Kaiser-Meyer-Olkin measure verified the sampling adequacy for the analysis, KMO $=.95$. Bartlett's test of sphericity, $\chi^{2}(1275)=7368.03, p$ $<.001$ indicated the correlations sufficiently large for PCA. An initial analysis was run to obtain eigenvalues for each component and eight of these delivered eigenvalues over Kaiser's criterion of 1. In combination these eight components explained $71.6 \%$ of the variance. However the scree plot and eigenvalues suggested a 4 factor solution accounting for $58.5 \%$ of the variance was acceptable as shown in Table 2. The first factor accounted for $30.3 \%$ of the variance on its own and the items loading on it clearly represent evaluations of the coach in terms of social identity with the team. The other three factors reflected evaluations of the coach as positive, negative, and respected respectively. However as the aim of this study was to develop a social identity leader scale, the first factor was focused on for the rest of the analysis.

We used the set of criteria proposed by Lamping, Schroter, Marquis, Marrel, Duprat-Lomon, and Sagnier (2002) and summarised by Smith, Lamping, Banerjee, Harwood, Foley, Smith et al. (2005) to set out some of the psychometric properties of the data for the social identity factor (see Table 3). The data used in this study was based on a cross sectional survey so test-retest reliability was not tested. However the items and factors perform well on all the other dimensions as shown in Table 3.

Next a principal component analysis (PCA) with orthogonal rotation (varimax) into simple structure was conducted on the 51 items reflecting team members' perceptions of their own relationship with their team. The Kaiser-Meyer-Olkin measure verified the sampling adequacy for the analysis, $\mathrm{KMO}=.93$. Bartlett's test of sphericity, $\chi^{2}(1275)=9986.048, p<.001$ indicated the correlations sufficiently large for PCA. An initial analysis was run to obtain eigenvalues for each component and eight of these delivered eigenvalues over Kaiser's criterion of 1 . In combination these eight components explained $67.4 \%$ of the variance. However the scree plot and eigenvalues suggest that only 3 factors accounting for $51.1 \%$ of the variance was identifiable. Scrutiny of the items loading on these factors suggest that the first factor accounting for $30 \%$ of the variance was the clearest measure of social identification with the team, and this 15-item factor is shown in Table 4.

Again using the criteria proposed by Lamping et al. (2002) and summarized by Smith et al. (2005), the items and factors perform well as shown in Table 4.

Pearson Product Moment Correlations between the new scales and the measures of sport confidence and sport motivation were calculated as shown in Table 5.

Table 3. Factor loadings and psychometric properties of the single factor Team Social Identity Scale (TSIS).

\begin{tabular}{|c|c|c|}
\hline $\begin{array}{l}\text { Factor 1: } \text { Team Social Identity: Eigenvalue = 8.9; } \\
\text { Variance }=59.89 \% ; \text { Cronbach Alpha }=.96\end{array}$ & Item-Total correlation & Factor loading \\
\hline 1) I am pleased to be a member of my team & .905 & .904 \\
\hline 2) I feel strong ties with my team mates & .906 & .887 \\
\hline 3) I feel good about my team & .804 & .880 \\
\hline 4) When I talk about my team I usually say we & .917 & .844 \\
\hline 5) I identify with my team mates & .757 & .822 \\
\hline 6) I am a worthy member of my team & .778 & .794 \\
\hline 7) I am glad to belong to my team & .745 & .793 \\
\hline 8) When someone praises my team, it feels like a compliment & .840 & .790 \\
\hline 9) I would rather belong to my team than any other & .657 & .774 \\
\hline 10) It would be accurate to describe me as a typical member & .835 & .770 \\
\hline
\end{tabular}


Table 4. Psychometric criteria and scale performance for the CSIS and the TSIS.

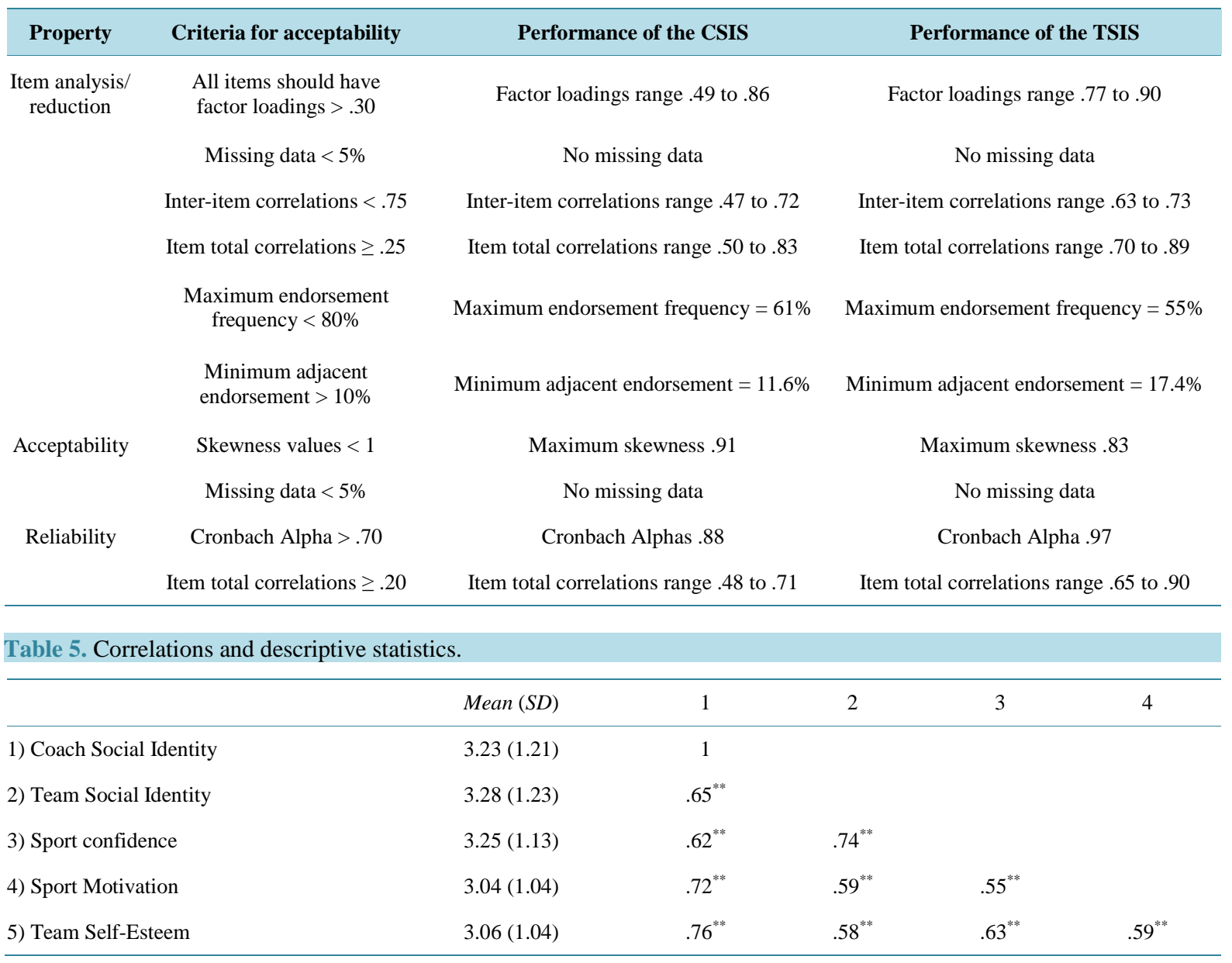

Note: ${ }^{*} p<.01 ;{ }^{* *} p<.001$.

Firstly the significant positive correlations between the two scales provide some evidence of concurrent validity as one might expect a positive relationship between perceptions of the coach as a prototypical team member and ratings of one's own identification with the team. Further evidence of concurrent validity is provided by the positive correlations between both scales and ratings of the coach as positive, and respected, and the negative correlations with ratings of the coach as negative. Finally the fact that both higher ratings of the coach as a prototypical team member and self identification with the team correlated positively with sport confidence, sport optimism, and intrinsic and extrinsic motivation provides additional evidence of predictive validity.

In order to further test the structure of the scales Confirmatory Factor Analysis was carried out using AMOS, which produced the results shown in Figure 1 and Figure 2. The Fit Indices confirm the fit of both measures to the data.

Finally since the correlation analysis shows a significant relationship between both Coach Social Identity (CSI) and Team Social Identity (TSI) and sport motivation and sport confidence a model was developed and tested using Structural Equation Modelling (SEM) with AMOS. The model proposed that CSI and TSI would both show positive and significant relationships with both sport motivation and sport confidence allowing TSI and CSI to be correlated and also allowing sport motivation and sport confidence to be correlated. The results shown in Figure 3 confirm that the model is a good fit for the data.

\section{Discussion}

The aim of this study was to develop and test measures which could be used in further exploring the utility of a social identity theory of leadership in sport coaching and this has been successfully accomplished. The pool of 


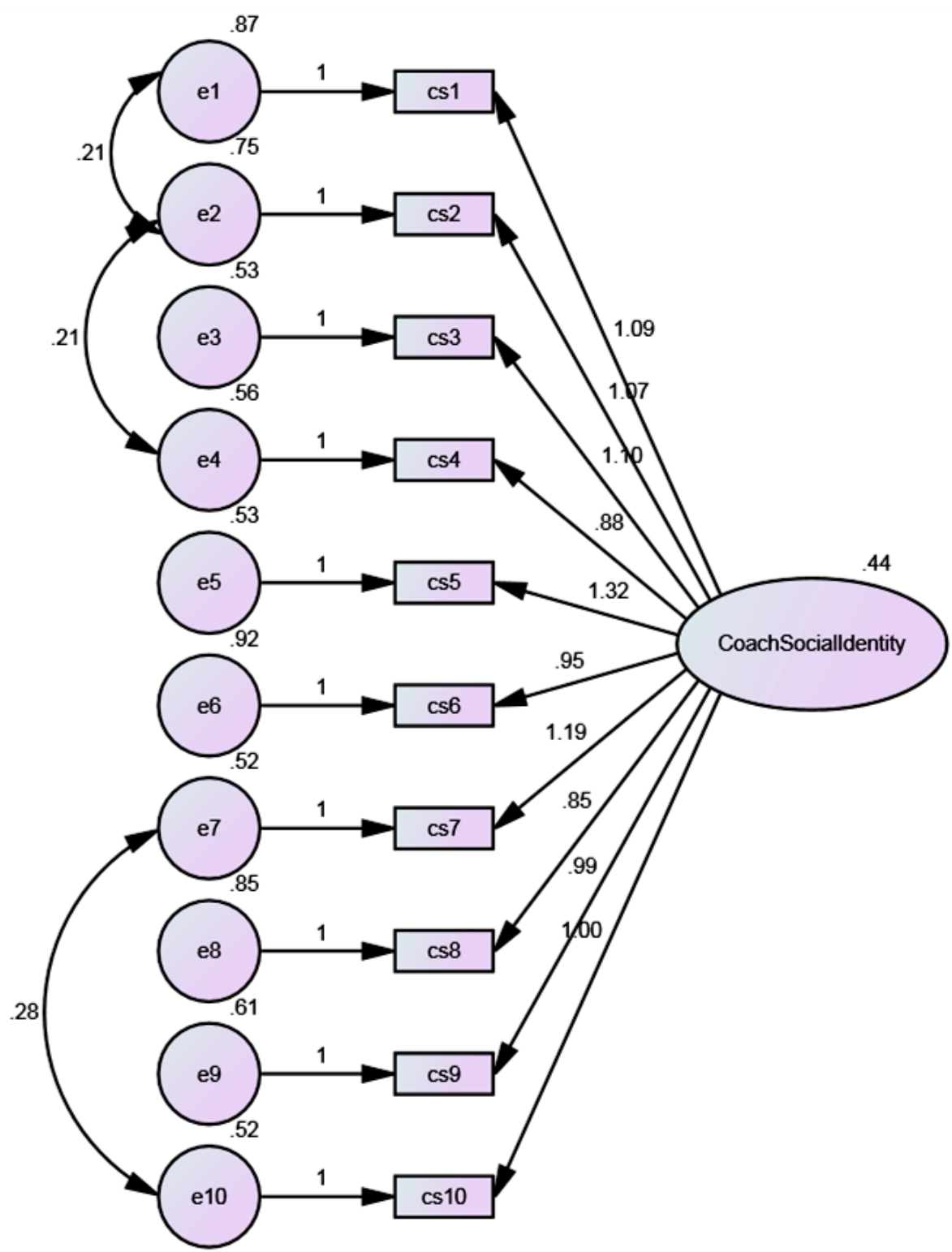

Figure 1. Confirmatory factor analysis of the Coach Social Identity Scale. Chi-square (32) = 61.357, $p<.001\left(\mathrm{C}_{\mathrm{Min}} / \mathrm{df}=1.9\right) ; \mathrm{CFI}=.98 ; \mathrm{IFI}=.98 ; \mathrm{RMSEA}=.05(\mathrm{Cl}: .03-.08) ; \mathrm{SRMR}=.04$.

items devised to provide team member ratings of their coach produced 4 factors, the first of which clearly reflects ratings of the coach as a prototypical team member and is accepted as a 10-item scale measuring Coach Social Identity. The pool of items applied to team members' self-ratings of identification with the team produced a strong 15-item Team Social Identity Scale. This provides initial support for the importance of social identifications in relation to sport teams. The psychometric properties demonstrated in line with Lamping et al. (2002) and Smith et al. (2005) provide strong support for the scale sin their initial stages. Clearly further testing of the reliability and validity of the scales is required and indeed as Anastasi suggests in her classic text reliability and validity should never be assumed as fixed and should be tested every time a scale is used (Anastasi, \& Urbina, 1997).

Previous research has established the relationship between both sport motivation and sport confidence and sport performance, and, while performance was not directly measured in this study, both measures of social identity are strongly related to motivation and confidence. The next stage in research should test their direct relationship with performance. 


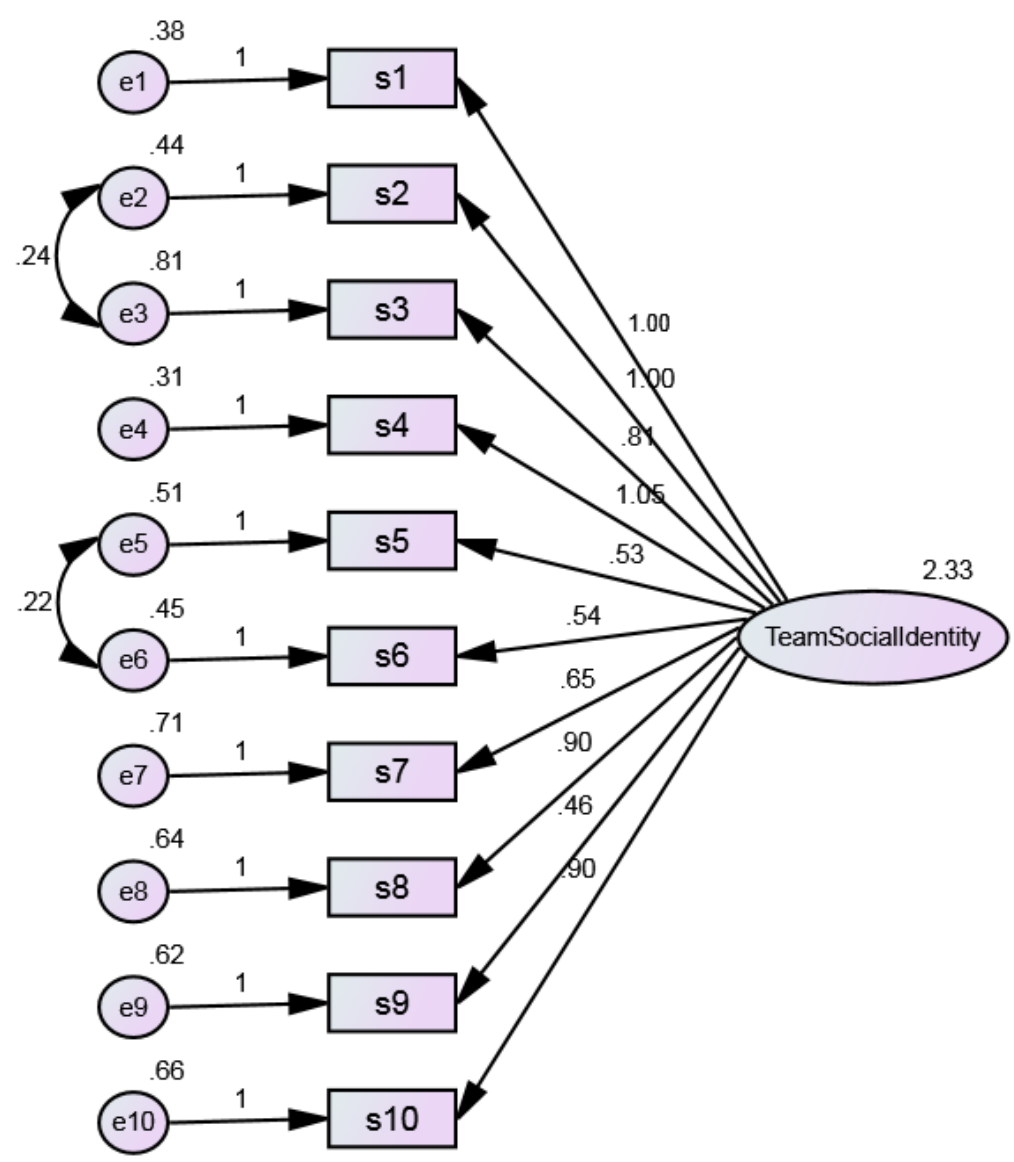

Figure 2. Confirmatory factor analysis of the Team Social Identity Scale. Chi-square (33) $=65.831$, $p<.001\left(\mathrm{C}_{\mathrm{Min}} / \mathrm{df}=1.99\right) ; \mathrm{CFI}=.99 ; \mathrm{IFI}=.99 ; \mathrm{RMSEA}=.06(\mathrm{Cl}: .04-.08) ; \mathrm{SRMR}=.04$.

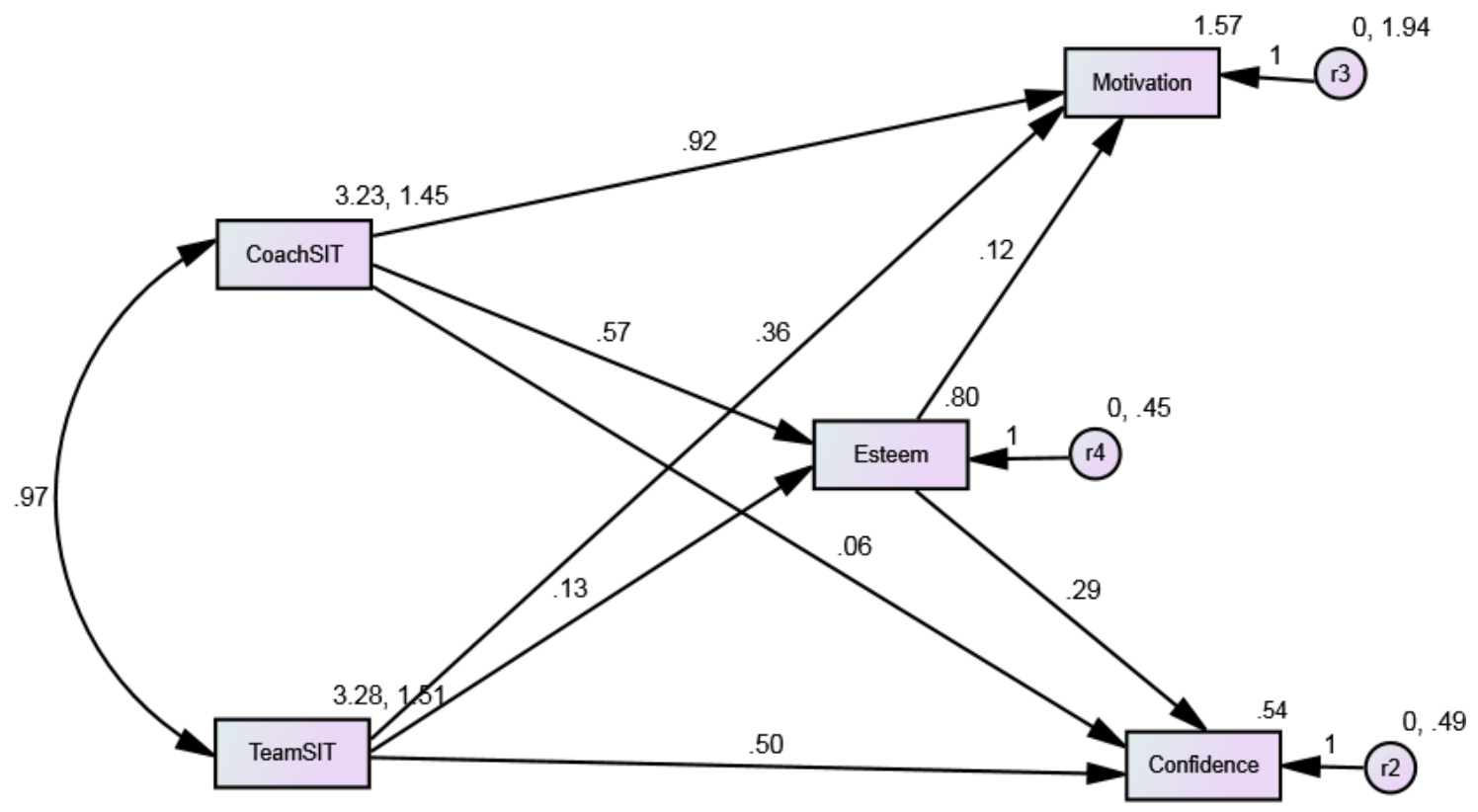

Figure 3. Path model for coach and team identification onto team self-esteem, sport motivation and sport conficence: Chi-square $(1)=.577, p=.45 ; \mathrm{IFI}=1.0 ; \mathrm{CFI}=1.0 ; \mathrm{RMSEA}=.00 ; \mathrm{SRMR}=.02$. 
The current data is cross sectional and based on sport science students, which limits the strength of conclusions that can be drawn. However the psychometric performance of the scales and the correlations with sport confidence and motivation provides strong preliminary evidence. The scales need to be further tested in larger samples of real life sport teams and coaches but this study does provide initial tools to begin exploring the area.

\section{References}

Allen, N. J., \& Meyer, J. P. (1990). The Measurement and Antecedents of Affective, Continuance and Normative Commitment to the Organization. Journal of Occupational Psychology, 63, 1-18. http://dx.doi.org/10.1111/j.2044-8325.1990.tb00506.x

Anastasi, A., \& Urbina, S. (1997). Psychological Testing (7th ed.). Upper Saddle River (NJ): Prentice Hall.

Avolio, B. J., Walumbwa, F. O., \& Weber, T. J. (2009). Leadership: Current Theories, Research, and Future Directions. Annual Review of Psychology, 60, 421-449. http://dx.doi.org/10.1146/annurev.psych.60.110707.163621

Bergami, M., \& Bagozzi, R. P. (2000). Self-Categorization and Commitment to Distinct Aspects of Social Identity in the Organization: Conceptualization, Measurement and Relation to Antecedents and Consequences. British Journal of Social Psychology, 39, 555-557. http://dx.doi.org/10.1348/014466600164633

Brown, R. J., Condor, F., Mathews, A., Wade, G., \& Williams, J. A. (1986). Explaining Intergroup Differentiation in an Industrial Organization. Journal of Occupational Psychology, 59, 273-287. http://dx.doi.org/10.1111/j.2044-8325.1986.tb00230.x

Callow, N., Smith, M. J., Hardy, L., Arthur, C. A., \& Hardy, J. (2009). Measurement of Transformational Leadership and Its Relationship with Team Cohesion and Performance Level. Journal of Applied Sport Psychology, 21, 395-412. http://dx.doi.org/10.1080/10413200903204754

Charbonneau, D., Barling, J., \& Kelloway, E. K. (2001). Transformational Leadership and Sports Performance: The Mediating Role of Intrinsic Motivation, Journal of Applied Social Psychology, 31, 1521-1534. http://dx.doi.org/10.1111/j.1559-1816.2001.tb02686.x

Chelladurai, P., \& Saleh, S. D. (1980) Dimensions of Leader Behaviors in Sport: Development of a Leadership Scale. Journal of Sport Psychology, 2, 34-45.

Cheney, G. (1982). Identification as a Process and Product: A Field Study. Unpublished Master's Thesis, Lafayette: Purdue University.

Deci, E. L., \& Ryan, R. M. (1985). Intrinsic Motivation and Self-Determination in Human Behavior. New York: Plenum Press. http://dx.doi.org/10.1007/978-1-4899-2271-7

Doosje, B., Ellemers, N., \& Spears, R. (1995). Perceived Intragroup Variability as a Function of Group Status and Identifcation. Journal of Experimental Social Psychology, 31, 410-436. http://dx.doi.org/10.1006/jesp.1995.1018

Ellemers, N., De Gilder, D., \& Haslam, S. A. (2004). Motivating Individuals and Groups at Work: A Social Identity Perspective on Leadership and Group Performance. Academy of Management Review, 29, 459-478.

Ellemers, N., Korkenaas, P., \& Ouwerkerk, J. (1999). Self-Categorisation, Commitment to the Group and Group Self-Esteem as Related but Distinct Aspects of Social Identity. European Journal of Psychology, 29, 371-389. http://dx.doi.org/10.1002/(SICI)1099-0992(199903/05)29:2/3<371::AID-EJSP932>3.0.CO;2-U

Haslam, S. A., Oakes, P. J., Reynolds, K. J., \& Turner, J. C. (1999). Social Identity Salience and the Emergence of Stereotype Consensus. Personality and Social Psychology Bulletin, 25, 809-818. http://dx.doi.org/10.1177/0146167299025007004

Haslam, S. A., \& Platow, M. J. (2001). Your Wish Is Our Command: The Role of Shared Social Identity in Translating a leader's Vision into Followers’ Action. In M. A. Hogg, \& D. J. Terry (Eds.), Social Identity Processes in Organizational Contexts (pp. 213-228). Philadelphia, PA: Psychology Press.

Haslam, S. A., Reicher, S., \& Platow, M. J. (2011). The New Psychology of Leadership: Identity, Influence, and Power. Hove: Psychology Press.

Hogg, M. A. (2001). A Social Identity Theory of Leadership. Personality and Social Psychology Review, 5, $184-200$. http://dx.doi.org/10.1207/S15327957PSPR0503_1

Hogg, M. A. (2006). Social Identity Theory. In P. Burke (Ed.), Contemporary Social Theories (pp. 111-136). Palo Alta, CA: Stanford University Press.

Hogg, M. A. (2007). Social Psychology of Leadership. In A. W. Krulanski, \& E. T. Higgins (Eds.), Social Psychology: Handbook of Basic Principles (2nd ed., pp. 716-733). New York: Guilford Press.

Hogg, M. A., \& Abrams, D. (1990). Social Motivation, Self-Esteem and Social Identity. In D. Abrams, \& M. A. Hogg (Eds.), Social Identity Theory: Constructive and Critical Advances (pp. 28-47). London: Harvester Wheatsheaf. 
Hogg, M. A., Fielding, K. S., Johnson, D., Masser, B., Russell, E., \& Svensson, A. (2006). Demographic Category Membership and Leadership in Small Groups: A Social Identity Analysis. The Leadership Quarterly, 17, 335-350. http://dx.doi.org/10.1016/j.leaqua.2006.04.007

Hinkle, S., Taylor, L. A., Fox-Cardamone, D. L., \& Crook, K. F. (1989). Intragroup Identification and Intergroup Differentiation: A Multicomponent Approach. British Journal of Social Psychology, 28, 305-317. http://dx.doi.org/10.1111/j.2044-8309.1989.tb00874.x

Karasawa, M. (1991). Towards an Assessment of Social Identity: The Structure of Group Identification and Its Effects on inGroup Evaluations. British Journal of Social Psychology, 30, 293-307. http://dx.doi.org/10.1111/j.2044-8309.1991.tb00947.x

Lamping, D. L., Schroter, S., Marquis, P., Marrel, A., Duprat-Lomon, I., \& Sagnier, P. P. (2002). The Community-Acquired Pneumonia Symptom Questionnaire: A New Patient-Based Outcome Measure to Evaluate Symptoms in Patients with Community-Acquired Pneumonia. Chest, 122, 920-929. http://dx.doi.org/10.1378/chest.122.3.920

Luthans, F., \& Avolio, B. J. (2003). Authentic Leadership Development. In K. S. Cameron, J. E. Dutton, \& R. E. Quinn (Eds.), Positive Organizational Scholarship (pp. 241-258). San Francisco, CA: Berrett-Koehler.

Luhtanen, R., \& Crocker, J. (1992). A Collective Self-Esteem Scale: Self-Evaluation of One’s Social Identity. Personality and Social Psychology Bulletin, 18, 302-318. http://dx.doi.org/10.1177/0146167292183006

Mael, F., \& Ashforth, B. E. (1992). Alumni and Their Alma Mater: A Partial Test of the Reformulated Model of Organizational Identification. Journal of Organizational Behavior, 13, 103-123. http://dx.doi.org/10.1002/job.4030130202

Mael, F. A., \& Tettrick, L. E. (1992). Identifying Organizational Identification. Educational and Psychological Measurement, 52, 813-824. http://dx.doi.org/10.1177/0013164492052004002

Manzo, L. G., Silva, J. M., \& Mink, R. (2001). The Carolina Sport Confidence Inventory. Journal of Applied Sport Psychology, 13, 260-274. http://dx.doi.org/10.1080/104132001753144400

Miller, L. M., \& Carpenter, C. L. (2009). Altruistic Leadership Strategies in Coaching: A Case Study of Jim Tressel of the Ohio State University. Strategies, 22, 9-12. http://dx.doi.org/10.1080/08924562.2009.10590826

Pelletier, L. G., Fortier, M., Vallerand, R. J., Briere, N. M., Tuson, K. M., \& Blais, M. R. (1995). The Sport Motivation Scale. Journal of Sport and Exercise Psychology, 17, 25-53.

Porter, L., Steers, R., Mowday, R., \& Boulian, P. (1974). Organizational Commitment, Job Satisfaction, and Turnover among Psychiatric Technicians. Journal of Applied Psychology, 59, 603-609. http://dx.doi.org/10.1037/h0037335

Rieke, M., Hammermeister, J., \& Chase, M. (2008). Servant Leadership in Sport: A New Paradigm for Effective Coach Behavior. International Journal of Sports Science and Coaching, 3, 227-239. http://dx.doi.org/10.1260/174795408785100635

Smith, S. C., Lamping, D. L., Banerjee, S., Harwood, R., Foley, B., Smith, P., Cook, J. C., Murray, J., Prince, M., Levin, E., Mann, A., \& Knapp, M. (2005). Measurement of Health-Related Quality of Life for People with Dementia: Development of a New Instrument (DEMQOL) and an Evaluation of Current Methodology. Health Technology Assessment, 9, 1-108.

Smoll, F. L., \& Smith, R. E. (1989). Leadership Behaviours in Sport: A Theoretical Model and Research Paradigm. Journal of Applied Sport Psychology, 19, 1522-1551.

Tajfel, H. (1982). Social Psychology of Intergroup Relations. Annual Review of Psychology, 33, 1-59. http://dx.doi.org/10.1146/annurev.ps.33.020182.000245

Vella, S. A., Oades, L. G., \& Crowe, T. P. (2010). The Application of Coach Leadership Models to Coaching Practice: Current State and Future Directions. International Journal of Sports Science and Coaching, 5, 425-434. http://dx.doi.org/10.1260/1747-9541.5.3.425 
Scientific Research Publishing (SCIRP) is one of the largest Open Access journal publishers. It is currently publishing more than 200 open access, online, peer-reviewed journals covering a wide range of academic disciplines. SCIRP serves the worldwide academic communities and contributes to the progress and application of science with its publication.

Other selected journals from SCIRP are listed as below. Submit your manuscript to us via either submit@scirp.org or Online Submission Portal.
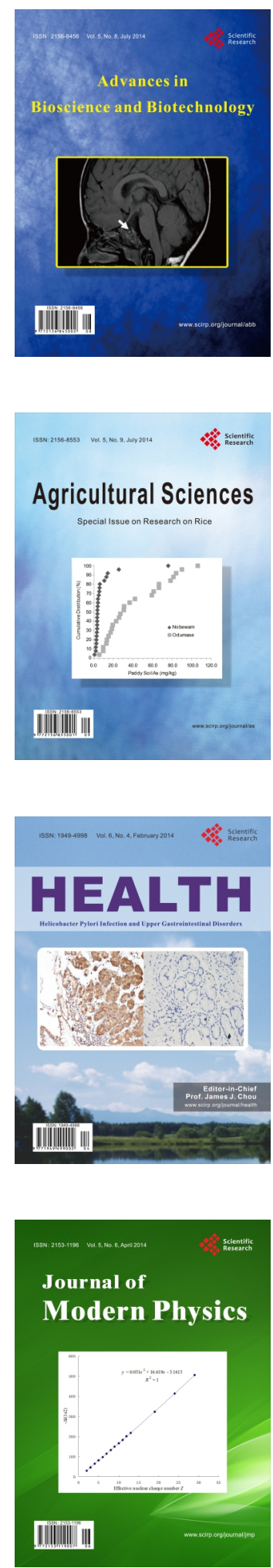
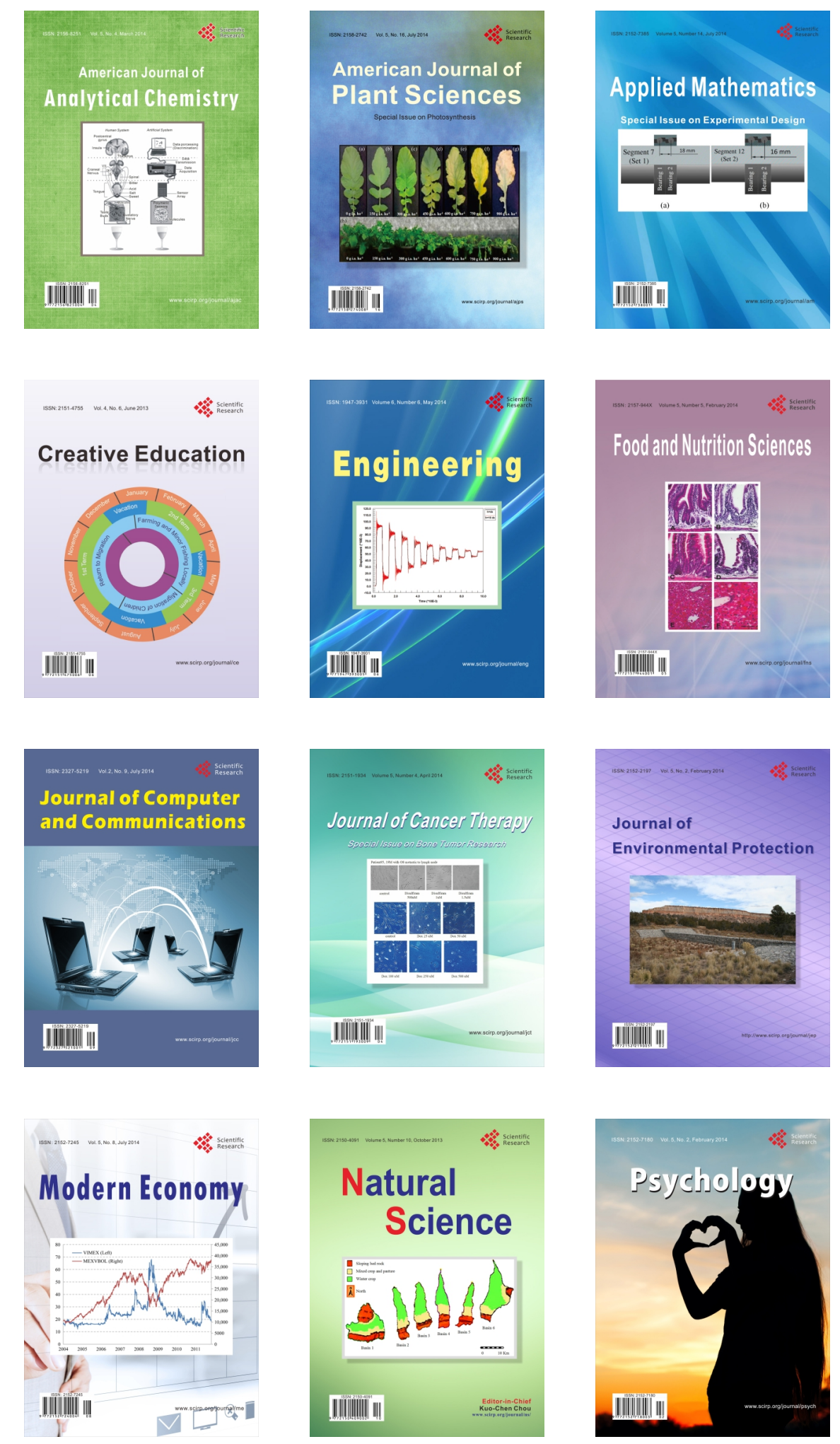